\title{
Epicardium in Heart Development
}

\author{
Yingxi Cao, Sierra Duca, and Jingli Cao \\ Cardiovascular Research Institute, Department of Cell and Developmental Biology, Weill Cornell Medical \\ College, Cornell University, New York, New York 10021, USA \\ Correspondence: jic4001@med.cornell.edu
}

The epicardium, the outermost tissue layer that envelops all vertebrate hearts, plays a crucial role in cardiac development and regeneration and has been implicated in potential strategies for cardiac repair. The heterogenous cell population that composes the epicardium originates primarily from a transient embryonic cell cluster known as the proepicardial organ (PE). Characterized by its high cellular plasticity, the epicardium contributes to both heart development and regeneration in two critical ways: as a source of progenitor cells and as a critical signaling hub. Despite this knowledge, there are many unanswered questions in the field of epicardial biology, the resolution of which will advance the understanding of cardiac development and repair. We review current knowledge in cross-species epicardial involvement, specifically in relation to lineage specification and differentiation during cardiac development.

$\mathrm{T}_{\mathrm{l}}^{\mathrm{h}}$ he epicardium is the outermost mesothelial layer of all vertebrate hearts. First described more than a century ago, the presence of the epicardium was later confirmed by electron microscopy studies in the 1960s (Kurkiewicz 1909; Manasek 1968, 1969). The epicardium was previously considered to passively cover the myocardium, and only over the past few decades has its importance in heart development and diseases been revealed (Riley 2012). Empirical evidence suggests that the epicardium is a critical player in heart development and regeneration by acting as a source of progenitor cells and essential signals (Limana et al. 2011; Masters and Riley 2014). The epicardium and its derived cells have been reported to secrete factors for cardiomyocyte (CM) growth and maturation during development. In addition, these cells contribute to cardiac fibroblasts, vascular smooth muscle cells (vSMCs), and pericytes, with controversial contributions to endothelial cells and CMs ( $\mathrm{Mi}-$ kawa and Gourdie 1996; Dettman et al. 1998; Gittenberger-de Groot et al. 1998; Manner 1999; Merki et al. 2005; Limana et al. 2007; Cai et al. 2008; Zhou et al. 2008a; Christoffels et al. 2009; Rudat and Kispert 2012). After cardiac injury, the epicardium is believed to reactivate developmental processes in both the highly regenerative teleost fish heart and the less regenerative mammalian heart by providing perivascular components and trophic signals for CM survival or division (Lepilina et al. 2006; Kikuchi et al. 2011; Smart et al. 2011; Zhou et al. 2011; Huang et al. 2012; Wang et al. 2013; Gemberling et al. 2015; Wei et al. 2015). Remarkably, the presence of an intact epicardium is essential for successful myocardial regeneration in zebrafish (Wang et al. 2015). All of these findings

Editors: Benoit G. Bruneau and Paul R. Riley

Additional Perspectives on Heart Development and Disease available at www.cshperspectives.org

Copyright (C) 2020 Cold Spring Harbor Laboratory Press; all rights reserved; doi: 10.1101/cshperspect.a037192

Cite this article as Cold Spring Harb Perspect Biol 2020;12:a037192 
Y. Cao et al.

indicate that the epicardium is a putative therapeutic candidate for novel heart repair strategies. Precise manipulation of the epicardium to enhance secretion of proregenerative factors and differentiation to coronary cell types would augment the regenerative response of the epicardium for therapeutic purposes. Despite these studies, there are still substantial knowledge gaps in our understanding of epicardial formation and differentiation during development and reactivation of the developmental program after cardiac injuries. Epicardial functions during heart regeneration have recently been reviewed elsewhere (Cao and Poss 2018; Simões and Riley 2018). By focusing on heart development, here we summarize current knowledge and highlight the controversies and hurdles in the field of epicardial biology.

\section{THE ORIGINS OF THE EPICARDIUM}

Epicardial cells are primarily derived from a transient, mesoderm-derived cell cluster in the embryo called the proepicardial organ (PE). First described in the chick embryo as pericardial villi, the $\mathrm{PE}$ is a cell protrusion from the venous pole of the embryonic heart tube, between the sinus venous and the liver bud (Manner 1992, 1993). The PE is a highly conserved structure among vertebrates including zebrafish, Xenopus, axolotls, mice, rats, and even humans (Komiyama et al. 1987; Fransen and Lemanski 1990; Hirakow 1992; Nesbitt et al. 2006; Jahr et al. 2008; Serluca 2008). Several conserved transcription factors, including Wilms tumor 1 (Wt1), T-box factor 18 (Tbx18), and Transcription factor 21 (Tcf21, also known as epicardin, pod1, or capsuling in mammals), are highly expressed in the PE and serve as a molecular signature of this structure.

Although the majority of PE induction studies were performed in the chick embryo because of the easy accessibility of the in ovo model, the exact mechanism of PE induction is still unclear. In chick embryos, gene expression analyses and 1,1'-dioctadecyl-3,3,3',3'-tetramethylindocarbocyanine perchlorate (DiI)-labeling experiments suggested that the PE and inflow myocardium are both derived from the same precursor pool of the splanchnic mesoderm (van Wijk et al. 2009). Weak bone-morphogenetic protein (BMP) signaling is essential for $\mathrm{PE}$ specification, whereas strong BMP signals promote myocardial differentiation (Fig. 1; Schlueter et al. 2006; van Wijk et al. 2009). Also, fibroblast growth factor (FGF) signaling is reported to promote $\mathrm{PE}$ formation by suppressing $\mathrm{BMP}$ signaling in the $\mathrm{PE}$ region through phosphorylated extracellular signalregulated kinase 1/2 (p-Erk1/2) (van Wijk et al. 2009). However, another study using chick embryos indicated that although FGF ligands are not involved in the induction or maintained expression of PE-specific genes such as Tbx18, they can act as either autocrine or paracrine growth factors to promote outgrowth of the $\mathrm{PE}$ (Fig. 1; Torlopp et al. 2010). Distinct from the



Figure 1. Bone morphogenetic protein (BMP) and fibroblast growth factor (FGF) signals are involved in the induction of the proepicardial organ (PE). In chick embryos, strong BMP signaling promotes myocardial differentiation of the precursor pool of the splanchnic mesoderm through p-Smad1/5/8, whereas weak BMP signaling stimulates PE formation. FGF signaling negatively regulates $\mathrm{BMP}$ signaling in the $\mathrm{PE}$ region via $\mathrm{p}$ Erk1/2 to promote PE formation, although whether FGF signaling is required for the induction or maintained expression of PE-specific genes, such as Tbx18, is controversial (van Wijk et al. 2009; Torlopp et al. 2010). In contrast, blocking BMP signaling in zebrafish embryos reduces $t b x 18$ and $t c f 21$ expression and $\mathrm{PE}$ specification, whereas elevated $b m p 2 b$ expression before PE formation induces ectopic expression of tbx18 (Liu and Stainier 2010). A, Atrium; V, ventricle; AVJ, atrioventricular junction; SV, sinus venosus. 
findings in the chick embryo, blocking BMP signaling in zebrafish (through the overexpression of a dominant-negative form of a Bmp receptor) led to a significant reduction in $t b \times 18$ and $t c f 21$ expression, whereas overexpression of $b m p 2 b$ before PE specification led to the ectopic expression of $t b \times 18$ (Liu and Stainier 2010). This suggests that the mechanisms for PE specification are organism-specific (Andrés-Delgado et al. 2019).

After PE formation, PE cells translocate to the myocardial surface to form the epicardium through direct contact and/or by releasing freefloating cell clusters (or cysts) into the pericardial cavity, depending on the model that was investigated (Fig. 2). In the chick, Xenopus, and axolotl models, the PE produces protrusions to form a tissue bridge between PE and the dorsal wall of the ventricle to allow the PE cells to migrate onto the myocardium (Fransen and Lemanski 1990;

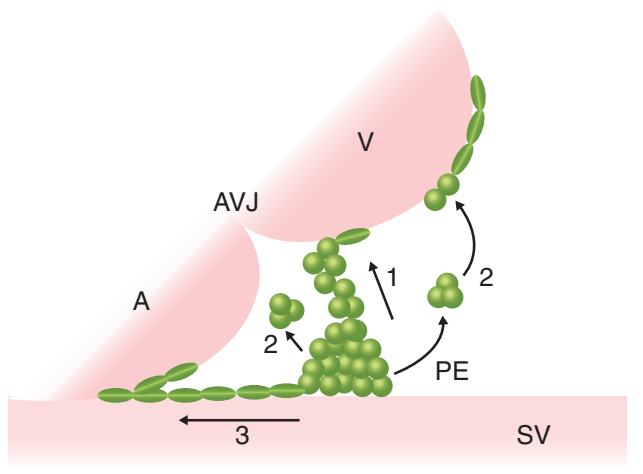

Figure 2. An overview of proepicardial organ (PE) translocation to the myocardium. Schematic of PE translocation to the myocardium showing three models across species. (1) Direct contact: In the chick, Xenopus, axolotl, zebrafish, and mouse, the PE produces protrusions to form a tissue bridge between the $\mathrm{PE}$ and the dorsal wall of the ventricle (or the PE contacts the ventricle directly) to allow the PE cells to migrate on to the myocardium. (2) Floating cysts: In zebrafish and mice, $\mathrm{PE}$ cell clusters detach from the proepicardial surface to form cysts, which float across the pericardial cavity to attach to the ventricular wall. (3) Migration: In mice, PE cells migrate from the SV toward the heart along the surface of the inflow tract. A, Atrium; V, ventricle; AVJ, atrioventricular junction; $\mathrm{SV}$, sinus venosus.
Nahirney et al. 2003; Jahr et al. 2008). BMPs expressed in the atrioventricular canal are believed to direct $\mathrm{PE}$ protrusion toward the heart tube in the chick embryo (Ishii et al. 2010). In mice, it was first reported that PE cell clusters detach from the proepicardial surface to form cysts, which then float freely across the pericardial cavity to attach to the myocardium around embryonic day 9 (E9.0) (Komiyama et al. 1987). Newer studies in mice suggest that both direct contact between the PE and myocardium and adhesion of free-floating PE cell cysts to the myocardium, underlie this translocation process (Rodgers et al. 2008; Li et al. 2017). Mice bearing a mutation of Par3, a polarity gene, display disrupted basoapical polarity and impaired cyst formation, suggesting that cell polarity is critical for PE cyst formation (Hirose et al. 2006). Similarly, an epicardium-specific deletion of $C d c 42$ also disrupts cell polarity and blocks the formation of PE protrusions and floating epicardial clusters (Li et al. 2017). Recent live imaging of PE development and translocation in zebrafish have also found that PE cell release and adhesion occur through both direct contact with the myocardium and with the floating clusters, which are driven by the heartbeat-induced flow of pericardial fluid (Peralta et al. 2013; Plavicki et al. 2014). Apart from these mechanistic models, Li et al. discovered an approach in mice in which $\mathrm{PE}$ cells grow from the sinus venosus toward the heart along the surface of the inflow tract (Fig. 2; Li et al. 2017). Therefore, multiple concurrent mechanisms underlie the process of PE cell translocation.

In addition to cells coming from the PE, Balmer et al. identified an additional subset of adult mouse epicardial cells located proximal to coronary vessels that are derived from $\mathrm{CD} 45^{+}$ hematopoietic cells, thus adding further heterogeneity to epicardial cells (detailed below) (Balmer et al. 2014).

\section{EPICARDIUM FORMATION AND EPITHELIAL-TO-MESENCHYMAL TRANSITION}

After translocating to the myocardial surface, $\mathrm{PE}$ cells flatten and spread over the surface of the 
Y. Cao et al.

ventricle, atrium, and the outflow tract (bulbus arteriosus) to form a contiguous cell sheet. Celladhesion molecules between epicardial cells and the myocardium mediate epicardial cell migration. For example, migrating epicardial cells express $\alpha 4$-integrin, which interacts with the $\alpha 4 \beta 1$-integrin ligand vascular cell-adhesion molecule-1 (VCAM1) expressed by the developing myocardium. Null mutant mice for either a4-integrin or Vcam1 displayed impaired epicardial cell attachment and migration and disrupted epicardium formation (Kwee et al. 1995; Yang et al. 1995; Sengbusch et al. 2002). In the chick embryo, epicardial migration is regulated by the epicardial expression of EphrinB ligands (the cell surface molecules for Eph tyrosine kinase receptors) and myocardial expression of the Eph receptor (Wengerhoff et al. 2010). In addition, the nuclear lamina protein lamin-B1 was reported to regulate epicardial cell migration by influencing the expression of cell-adhesion genes in mice (Tran et al. 2016). Despite these findings, it is still unclear what signals drive the migration process and whether there are heart chamber-specific differences in epicardium formation. Of note, the human ventricular epicardium has multiple cell layers, whereas the atrial epicardium is a monolayer (Risebro et al. 2015). Epicardial cells in both chambers also display differences in morphology and differentiation potential (Risebro et al. 2015). Consequently, it would be interesting to address how these differences are generated and how they might affect epicardial function in heart development and regeneration. Recent success in generating human embryonic stem cell-derived epicardial cells will facilitate further studies on epicardial cell differentiation and lineage commitment (Witty et al. 2014; Iyer et al. 2015).

As soon as a primitive epicardium forms, a group of epicardial cells delaminate from the epicardium and undergo epithelial-to-mesenchymal transition (EMT), enter the subepicardial domain, and give rise to epicardium-derived cells (EPDCs) (Lie-Venema et al. 2007). A study by $\mathrm{Wu}$ and colleagues found that epicardial cell proliferation is required for EMT and that directed spindle orientation of epicardial cells controls cell entry into the myocardium
(Wu et al. 2010). The authors examined the spindle orientation of epicardial cells in E12.5 and E13.5 mouse embryos; they found that epicardial cells divide either parallel or perpendicular to the basement membrane. Parallel division keeps both daughter cells in the epicardium, whereas perpendicular division causes one daughter cell to remain in the epicardium while the second daughter cell enters the myocardium. Deletion of $\beta$-catenin or Numb, which are both colocalized to adherens junctions, disrupts the adherens junctions and leads to randomized mitotic spindle orientation and impaired EMT of epicardial cells (Wu et al. 2010). However, it is unclear whether the capacity for EMT is randomly distributed across the epicardium or specified early to a subset of cells.

Several signals are reported to influence epicardial cell EMT. These signals include, but are not restricted to, transforming growth factor $\beta$ (TGF- $\beta$ ), FGF, Sonic hedgehog (Shh), retinoic acid (RA), Hippo/Yap, platelet-derived growth factor (PDGF), thymosin $\beta 4$ (T $\beta 4$ ), and extracellular matrix (ECM) components (e.g., hyaluronic acid [HA]; integrin) (Morabito et al. 2001; Dettman et al. 2003; Molin et al. 2003; Wada et al. 2003; Merki et al. 2005; Compton et al. 2006; Lavine et al. 2006; Olivey et al. 2006; Smart et al. 2007; Zamora et al. 2007; Austin et al. 2008; Sridurongrit et al. 2008; Craig et al. 2010; Vega-Hernandez et al. 2011; Missinato et al. 2015; Singh et al. 2016). For instance, the addition of the TGF- $\beta$ ligands to epicardial explant cultures from chicken and mouse promotes epicardial EMT and SMC differentiation, whereas epicardial-specific deletion of the receptor Alk5 in mice abolishes EMT and impairs the formation of the SMC layer and capillary vessels in vivo (Molin et al. 2003; Compton et al. 2006; Olivey et al. 2006; Austin et al. 2008; Sridurongrit et al. 2008). TGF- $\beta$ also stimulates HA secretion, which is required for epicardial migration and EMT (Craig et al. 2010; Missinato et al. 2015). Similarly, the addition of PDGF ligands or FGF1/2/7 to epicardial explant cultures induces epicardial EMT and SMC differentiation (Morabito et al. 2001; Wada et al. 2003). In mice, myocardial-derived FGF10 interacts with its receptors FGFR1 and FGFR2b in 
the epicardium to induce epicardial invasion into the myocardium and fibroblast differentiation (Vega-Hernandez et al. 2011). RA signaling regulates epicardial EMT through binding to the epicardial-expressed retinoid $\mathrm{X}$ receptors (RXRs) (Merki et al. 2005). Notably, RA induces the expression of FGF2 and FGF9 in the epicardial cells, which activates myocardial FGF signaling through FGFR1/2. The myocardial FGF signaling further triggers Shh activation in the epicardium, which enhances epicardial cell EMT and coronary vascular development, possibly by stimulating myocardial expression of vascular endothelial growth factors (VEGFs) and angiopoietin-2 (Ang-2) (Lavine et al. 2006, 2008). In addition, inhibition of Hippo signaling mediators Yap and Taz leads to impaired epicardial EMT and coronary vasculature formation (Singh et al. 2016). These findings suggest that there is intensive signaling cross talk between the epicardium and myocardium that underlie epicardial EMT. Notably, these signals not only influence epicardial EMT but also regulate epicardial cell differentiation. However, whether these two processes are sequential or occur concurrently remains unclear. Aside from these signals, transcription factors such as Wt1, tcf21, Snail1, myocardin-related transcription factors (MRTFs), and Nuclear Factor of Activated T Cells 1 (Nfatc1) are also involved in the regulation of epicardial cell EMT (Martínez-Estrada et al. 2010; Combs et al. 2011; von Gise et al. 2011; Acharya et al. 2012; Trembley et al. 2015).

\section{EPICARDIUM AS A SOURCE OF PROGENITOR CELLS}

As outlined above, epicardial cells and EPDCs are highly plastic, giving rise to multiple cardiac cell types during development (Fig. 3). However, relevant regulatory sequences for specific pan-epicardial markers have yet to be identified; thus, the complete lineages of epicardial cells remain uncertain. This ambiguity results from an inability to perform genetic fate-mapping with specific regulatory sequences that induce a permanent label within the epicardial cell population and its progeny in transgenic animals. Below, we highlight our current understanding of the contribution of epicardial cells to various lineages within the heart.

\section{Contribution to Coronary Cells and Fibroblasts}

Studies in different animal models have reached a consensus that epicardial cells and EPDCs are

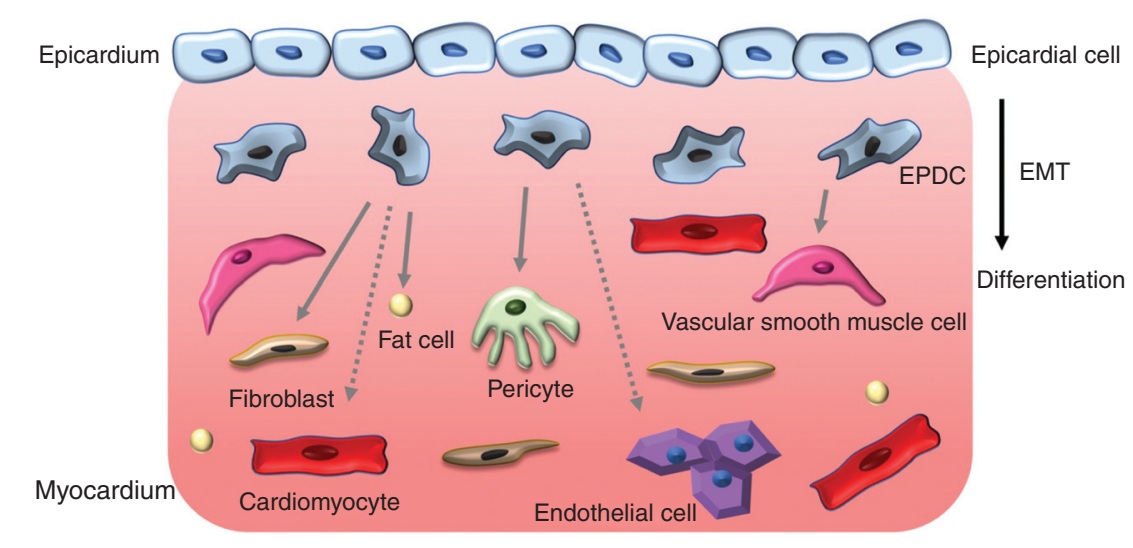

Figure 3. Cellular contributions of epicardium during heart development. Epicardial cells enter the myocardium through epithelial-to-mesenchymal transition (EMT) to form epicardium-derived cells (EPDCs), which differentiate into fibroblasts, vascular smooth muscle cells (vSMCs), pericytes, fat cells, and, possibly, endothelial cells and cardiomyocytes. Solid arrows denote consensus cell fates, whereas dashed arrows indicate controversial contributions. 
Y. Cao et al.

the major source of cardiac fibroblasts, while also contributing to perivascular SMCs and pericytes during development. Early studies in avian models suggested controversial epicardial contributions to coronary endothelial cells and endocardial cells, in addition to the consensus cell fates (Mikawa and Fischman 1992; Mikawa and Gourdie 1996; Manner 1999; Pérez-Pomares et al. 2002b; Guadix et al. 2006). These lineage-tracing studies used dye labeling, cell transplantation, and retroviral vector tagging to trace epicardial cell fates in chick embryos, which may not be as efficient and specific as a genetic fate-mapping approach (Table 1). In mammals and zebrafish, genetic fate-mapping has used regulatory elements to drive a tamoxifen-inducible Cre recombinase (Cre-ER) in conjunction with a floxed fluorescent reporter to trace the fate of $\mathrm{Cre}^{+}$cells. Regulatory sequences used thus far to trace epicardial cells have been derived from genes Tcf21, Wt1, Tbx18, Scleraxia (Scx), and Semaphorin 3D (Sema3D) (Cai et al. 2008; Zhou et al. 2008a,b; Christoffels et al. 2009; Katz et al. 2012; Rudat and Kispert 2012; Braitsch et al. 2013). These markers have overlapping expression domains, but also label distinct additional cell types. Also, some of the markers only label embryonic or injury-activated epicardial populations. Even so, studies in mammals using these regulatory sequences agree that epicardial cells are a primary source of cardiac fibroblasts during heart development (Acharya et al. 2012; Braitsch et al. 2012; Ali et al. 2014; Moore-Morris et al. 2014, 2016). Epicardial cells also contribute to the vSMCs and pericytes that compose the walls of coronary vessels (Cai et al. 2008; Zhou et al. 2008a; Grieskamp et al. 2011). The epicardial contribution to coronary endothelium was reported when tracing the PE or epicardial cells expressing Scx and Sema3D (Katz et al. 2012). However, the endothelial cell fate was not supported in other studies assessing $T b \times 18^{+}$or $W t 1^{+}$epicardial cells (Cai et al. 2008; Zhou et al. 2008a; Grieskamp et al. 2011). Of note, Scx or Sema3D mark distinct PE subpopulations from $\mathrm{Tb} \times 18^{+}$and $\mathrm{Wt1}^{+}$cells. Generally, the consensus is that the epicardial contribution to endothelial cells is very minor in comparison to the more substantial sinus venous and endocardium contribution (for a review, see Leung et al. 2016). Nevertheless, the epicardium is an important signaling node for coronary vessel formation, as discussed in the section on the epicardium as an essential signaling node.

In zebrafish, $t c f 21$ is used as a pan-epicardial marker that has the widest and most specific expression (compared with wt 1 and tbx18) in epicardial cells and EPDCs in both quiescent and active (developing or heart-injured) cells (Lepilina et al. 2006; Perner et al. 2007; González-Rosa et al. 2011; Kikuchi et al. 2011; Schnabel et al. 2011). Genetic fate-mapping using the tcf21:CreER line showed that epicardial cells contribute to perivascular cells (likely SMCs), but not to CMs in developing and regenerating hearts (Kikuchi et al. 2011). Another study using the $w t 1 b$ :GFP line and transplantation method similarly showed that there are epicardial contributions to perivascular SMCs and fibroblasts, but not to CMs (González-Rosa et al. 2012). In particular, zebrafish heart fibroblasts have not been well-characterized owing to a lack of specificity in the markers currently used. For example, in addition to fibroblasts, $\alpha$-smooth muscle actin ( $\alpha$-SMA) labels SMCs and pericytes, vimentin labels endocardium, myosin light chain kinase (MLCK) labels SMCs and thrombocytes, and colla2 and periostin label epicardial cells (Lane et al. 1983; Zeisberg et al. 2007; Tournoij et al. 2010; Zhou et al. 2010; Ito et al. 2014; Moore-Morris et al. 2014, 2015). Despite this specificity issue, it is generally accepted that the major epicardial lineage in zebrafish consists of perivascular cells and not endothelial cells or CMs, agreeing with the consensus in mammals. Of note, it is unclear whether there are $t c f 21^{-}$ epicardial cells in zebrafish.

\section{Contribution to Cardiomyocytes}

The primary goal of heart regeneration is to generate new CMs. A critical question about the epicardium is whether it can contribute to CMs during development and heart regeneration in mammals and, if so, to what extent. Two reports in 2008 using transgenic mouse tools (albeit with the aforementioned specificity is- 
Epicardium in Heart Development

Table 1. Epicardial cell fates during heart development

\begin{tabular}{|c|c|c|c|}
\hline Cell fate & Species & Methods and models & Reference(s) \\
\hline \multirow[t]{9}{*}{$\begin{array}{l}\text { Smooth muscle } \\
\text { cell }\end{array}$} & \multirow[t]{3}{*}{ Chick } & $\begin{array}{l}\text { Dye labeling, retroviral labeling, and cell } \\
\text { transplantation }\end{array}$ & $\begin{array}{l}\text { Mikawa and Gourdie 1996; Perez- } \\
\text { Pomares et al. 2002a }\end{array}$ \\
\hline & & $\begin{array}{l}\text { Dye labeling, retroviral labeling, and cell } \\
\text { transplantation (quail-chick chimeras) }\end{array}$ & Dettman et al. 1998 \\
\hline & & Cell transplantation (quail-chick chimeras) & $\begin{array}{l}\text { Gittenberger-de Groot et al. 1998; } \\
\text { Manner 1999; Pérez-Pomares et al. } \\
\text { 2002b; Guadix et al. } 2006\end{array}$ \\
\hline & \multirow[t]{6}{*}{ Mouse } & $\begin{array}{l}W t 1^{\operatorname{Cre}} ; \operatorname{Rosa} 26^{f_{S L z}} \text { or Z/Red } W t 1^{\operatorname{CreERT2}} \\
\quad \operatorname{Ros} 26^{f_{s L z}} \text { or Z/Red }\end{array}$ & Zhou et al. $2008 \mathrm{a}$ \\
\hline & & $T b \times 18^{\text {Cre }} ; R 26 R^{\text {lacZ }}$ & Cai et al. 2008 \\
\hline & & $\operatorname{Tb} \times 18^{\mathrm{Cre}} ; \operatorname{Ros} a 26^{m T / m G}$ & Grieskamp et al. 2011 \\
\hline & & $\begin{array}{l}\text { Scx }{ }^{G F P C r e} ; R_{26 R^{l a c Z}} \\
\quad \text { Sema3 } 3 D^{G F P C r e} ; R 26 R^{\text {lacZ }}\end{array}$ & Katz et al. 2012 \\
\hline & & $\begin{array}{l}\text { G2-Gata4 }{ }^{\text {Cre }} ; \text { Rosa } 26^{\text {YFP }} \\
\text { Wt1 }^{\text {CreYFP+ }} ;{ }_{;} \text {Rosa } 26^{\text {YFP }}\end{array}$ & Cano et al. 2016 \\
\hline & & $\begin{array}{l}W t 1^{\text {CreER }} ; \text { Rosa } 26^{R F P} \\
\quad \operatorname{Tb} \times 18^{\text {Cre }} ; \operatorname{Ros} a 26^{\text {RFP }}\end{array}$ & Liu et al. 2016 \\
\hline \multirow[t]{9}{*}{ Fibroblast } & \multirow[t]{3}{*}{ Chick } & $\begin{array}{l}\text { Dye labeling, retroviral labeling, and cell } \\
\text { transplantation }\end{array}$ & $\begin{array}{l}\text { Mikawa and Gourdie 1996; Perez- } \\
\text { Pomares et al. 2002a }\end{array}$ \\
\hline & & $\begin{array}{l}\text { Dye labeling, retroviral labeling, and cell } \\
\text { transplantation (quail-chick chimeras) }\end{array}$ & Dettman et al. 1998 \\
\hline & & Cell transplantation (quail-chick chimeras) & $\begin{array}{l}\text { Gittenberger-de Groot et al. 1998; } \\
\text { Manner 1999; Pérez-Pomares et al. } \\
\text { 2002b; Guadix et al. } 2006\end{array}$ \\
\hline & \multirow[t]{6}{*}{ Mouse } & $T b \times 18^{\mathrm{Cre}} ; R 26 R^{\text {lac } Z}$ & Cai et al. 2008 \\
\hline & & Tbx $18^{\text {Cre }} ; \operatorname{Ros} a 26^{m T / m G}$ & Grieskamp et al. 2011 \\
\hline & & $W t 1^{G F P C r e} ; R 26 R^{m T / m G}$ & Wessels et al. 2012 \\
\hline & & $T c f 21^{i C r e} ; R 26 R^{Y F P}$ or $R 26 R^{t d T}$ & Acharya et al. 2012 \\
\hline & & Scx ${ }^{G F P C r e} ; R 26 R^{\text {lacZ }}$ Sema3 ${ }^{G F P C r e} ; R 26 R^{\text {lacZ }}$ & Katz et al. 2012 \\
\hline & & $T b \times 18^{C r e} ; R 26 R^{m T / m G}$ & Ali et al. 2014 \\
\hline \multirow[t]{8}{*}{ Endothelial cell } & \multirow[t]{2}{*}{ Chick } & $\begin{array}{l}\text { Dye labeling, retroviral labeling, and cell } \\
\text { transplantation }\end{array}$ & $\begin{array}{l}\text { Mikawa and Gourdie 1996; Perez- } \\
\text { Pomares et al. 2002a }\end{array}$ \\
\hline & & Cell transplantation (quail-chick chimeras) & $\begin{array}{l}\text { Gittenberger-de Groot et al. 1998; } \\
\text { Manner 1999; Pérez-Pomares et al. } \\
\text { 2002b; Guadix et al. } 2006\end{array}$ \\
\hline & \multirow[t]{6}{*}{ Mouse } & $\begin{array}{l}W t 1^{\mathrm{Cre}} ; \operatorname{Ros} a 26^{f s L z} \text { or Z/Red } W t 1^{\operatorname{CreERT2}} \\
\quad \operatorname{Rosa} 26^{f_{s L z}} \text { or Z/Red }\end{array}$ & Zhou et al. 2008a \\
\hline & & 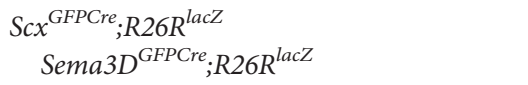 & Katz et al. 2012 \\
\hline & & G2-Gata4 ${ }^{\text {Cre }} ;$ Rosa $26^{\text {YFP }}$ & Cano et al. 2016 \\
\hline & & $W t 1^{\mathrm{CreYFP+}} ; \operatorname{Rosa}_{26^{Y F P}}$ & Cano et al. 2016 \\
\hline & & $W t 1^{\text {CreERT2 }} ; \operatorname{Rosa} 26^{\text {YFP }}$ & Cano et al. 2016 \\
\hline & & $W t 1^{\text {CreER }} ; \operatorname{Ros} a 26^{R F P}$ & Liu et al. 2016 \\
\hline \multirow[t]{3}{*}{ Endocardial cell } & \multirow[t]{2}{*}{ Chick } & $\begin{array}{l}\text { Dye labeling, retroviral labeling, and cell } \\
\text { transplantation (quail-chick chimeras) }\end{array}$ & Dettman et al. 1998 \\
\hline & & Cell transplantation (quail-chick chimeras) & $\begin{array}{l}\text { Gittenberger-de Groot et al. 1998; } \\
\text { Manner } 1999\end{array}$ \\
\hline & Mouse & Scx ${ }^{\text {GFPCre }} ; R 26 R^{\text {lacZ }}$ & Katz et al. 2012 \\
\hline Cardiomyocyte & Mouse & $\begin{array}{l}W t 1^{\text {Cre }} ; \operatorname{Rosa} 26^{f S L z} \text { or Z/Red } W t 1^{\text {CreERT2 }} \\
\text { Rosa } 26^{f L L z} \text { or Z/Red }\end{array}$ & Zhou et al. 2008a \\
\hline
\end{tabular}

Continued 
Y. Cao et al.

Table 1. Continued

\begin{tabular}{|c|c|c|c|}
\hline Cell fate & Species & Methods and models & Reference(s) \\
\hline \multirow{5}{*}{ Pericytes } & \multirow{5}{*}{ Mouse } & $\mathrm{Tb} \times 18^{\mathrm{Cre}} ; \mathrm{R} 26 \mathrm{R}^{\text {lacZ }}$ & Cai et al. 2008 \\
\hline & & 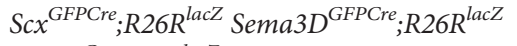 & Katz et al. 2012 \\
\hline & & $T b \times 18^{\text {Cre }} ; R 26 R^{\text {lac } Z}$ & Cai et al. 2008 \\
\hline & & $W t 1^{C r e E R} ; \operatorname{Ros} a 26^{R F P}$ & Liu et al. 2016 \\
\hline & & $W t 1^{\operatorname{CreERT2}} ; \operatorname{Ros} a^{m T m G}$ & Trembley et al. 2015 \\
\hline Adipocyte & Mouse & $T b \times 18^{C r e} ; R 26 R^{Y F P}$ & Yamaguchi et al. 2015 \\
\hline $\begin{array}{l}\text { Perivascular } \\
\text { cells }\end{array}$ & Zebrafish & tcf21:CreER;gata5:RnG & Kikuchi et al. 2011 \\
\hline
\end{tabular}

sues) indicated that epicardial cells contribute to CMs during development in mice (Cai et al. 2008; Zhou et al. 2008a). In a first report, Cai et al. generated a nuclear $\operatorname{LacZ}\left(T b \times 18^{\text {nLacZ/+ }}\right)$ and a Cre $\left(\mathrm{Tb} \times 18^{\mathrm{Cre} /+}\right)$ knock-in into the endogenous Tbx18 locus to label and trace the epicardial lineages during development (Cai et al. 2008). They found that the Tbx $18^{+} \mathrm{PE}$ cells contribute to vSMCs and pericytes (marked by $P d g f r b$ ), fibroblasts (marked by Col1a2), and cells that show a CM identity (positive for cardiac troponin T, troponin I, MF20, Gata4, and $N k \times 2.5)$. However, the CM contribution was later challenged by a finding that Tbx18 itself is expressed in the myocardium (Christoffels et al. 2009). In a second report, a GFPCre cassette was knocked into the endogenous Wt1 start codon $\left(W t 1^{\text {GFPCre/+}}\right)$ to label and trace the $W t 1^{+}$cells (Zhou et al. 2008a). Zhou et al. found that a subset of these cells differentiated into functional CMs $\left(T n n t 2^{+}, A c t n 1^{+}\right.$, and electrically coupled with non-Wt1-derived CMs) that comprised $7 \%-10 \%$ of $\mathrm{CMs}$ in the ventricle and $18 \%$ in the atrium during normal heart development. In addition, lineage tracing using a CreERT2 knock-in line $\left(W t 1^{\text {CreERT2 }}\right.$ ) confirmed the contribution to CMs when the mice were treated with tamoxifen at E10.5 and E11.5 and assessed at E16.5 (Zhou et al. 2008a). The $W t 1^{\text {GFPCre/+ }}$ and $W t 1^{\text {CreERT2 }}$ lines have been widely used to label the epicardial lineages ever since. A following study, however, challenged the cellular specificity of Wt1 during development by showing endothelial cell expression in addition to PE and epicardium expression (Rudat and Kispert 2012). Moreover, the $W t 1^{\text {GFPCre/+ }}$ line showed ectopic recombina- tion in CMs before the formation of the PE (Rudat and Kispert 2012). Although there may be CMs derived from $t b \times 18^{-} / w t 1^{-}$epicardial cells in mice, the consensus in the field is that the epicardial contribution to CMs is minimal, if it occurs at all. Of note, the epicardial contribution to CMs has not been reported in the avian models, which needs further investigation. Even if epicardial cells do not naturally contribute to CMs, T $\beta 4$ was identified as a regeneration factor that can prime epicardial cells to differentiate into myocytes in rare events when applied before myocardial infarction in mice, suggesting that the epicardium has a potential for reprogramming into CMs (Smart et al. 2007, 2011).

\section{Contributing to Other Cell Types}

Lineage-tracing studies in mice have also found that the $T b x 18^{+}$or $W t 1^{+}$epicardial cells are the origin of cardiac adipose tissue during development and after heart injury (Liu et al. 2014; Yamaguchi et al. 2015; Zangi et al. 2017). Of note, the cardiac adipose tissue is not only important for cardiac physiology but also a risk marker for cardiac diseases such as atrial fibrillation (Antonopoulos and Antoniades 2017), further supporting the important role of the epicardium in heart development. In addition, Chong et al. claimed that mouse PE cells (defined by $P D G F R \alpha$ expression) give rise to adult cardiac-resident mesenchymal stem cells, which have multilineage differentiation potential, including functioning in an adventitial location in the cardiac perivascular system (Chong et al. 2011). Lineage tracing indicated that these PE-derived cells autonomously emerge from the 
coronary vascular bed and are still present after fetal development. Nevertheless, extensive lineage mapping of these cardiac-resident mesenchymal stem cells is required to further illuminate epicardial differentiation potential.

\section{Cellular Heterogeneity}

An unanswered question regarding epicardial lineages is whether cell fates are committed within the epicardium during development. This notion is favored by several lines of evidence that show the cellular heterogeneity of $\mathrm{PE}$ and epicardial cells. The widely used markers $T c f 21, T b x 18$, and $W t 1$ display mosaic expression patterns by labeling subpopulations of the developing epicardium in both the chick and mouse heart (Braitsch et al. 2012; Katz et al. 2012), with most of the $S c x^{+}$and Sema3 $D^{+} \mathrm{PE}$ cells being $T b \times 18^{-}$and $W t 1^{-}$in mice (Katz et al. 2012). Further, the $C D 45^{+}$hematopoietic cells were reported to give rise to a subset of the developing epicardium (Balmer et al. 2014). Moreover, the anatomical difference of human epicardial cells between heart chambers also supports the cellular heterogeneity with the epicardium (Risebro et al. 2015). In zebrafish, tbx18 or $w t 1$ only mark subsets of $t c f 21^{+}$epicardial cells (Kikuchi et al. 2011). An experimental test of epicardial and EPDC heterogeneity has been performed in adult zebrafish through single-cell transcriptome analysis of the $t c f 21^{+}$cells (Cao et al. 2016). In this study, the investigators profiled dozens of $\mathrm{GFP}^{+}$cells purified from the uninjured hearts of zebrafish carrying a $t c f 21$ : $n u c E G F P$ reporter. Analysis suggested the presence of at least three cell subsets, defined by expression signatures. Although the origin and cellular plasticity of these subtypes were not addressed, this study identified potential candidate genes for labeling epicardial and EPDC subtypes, providing a resource to identify subsetspecific markers. Further validation of those markers will derive new reporters for additional lineage-tracing experiments. In another study, Bollini et al. revealed the heterogeneity of T $\beta 4$ primed EPDCs, which showed diverse cardiovascular potential among subsets (Bollini et al. 2014). Nevertheless, the above information regarding transcriptome heterogeneity is not enough to address when cell fates are committed owing to the fact that each subset labeled by a single marker gave rise to multiple lineages. Further fate-mapping analysis at the single-cell resolution with specific markers combined with human ES-derived epicardial cells (Witty et al. 2014; Iyer et al. 2015) will be necessary.

\section{EPICARDIUM AS AN ESSENTIAL SIGNALING NODE}

As mentioned above, multiple signaling pathways mediate epicardium-myocardium interactions to regulate epicardial EMT, which impact epicardial cell differentiation to perivascular cell types and fibroblasts as well as additional effects on heart development. Apart from these cellautonomous signals, the epicardium and its derivatives serve as a signaling center for $\mathrm{CM}$ proliferation and coronary vessel development. The epicardium also provides ECM components to support cardiac tissue structure during development and regeneration. Identification of epicardial-derived mitogens for CMs and angiogenic factors is crucial for developing therapeutic strategies. This topic was reviewed elsewhere in the context of heart regeneration (Cao and Poss 2018; Simões and Riley 2018). Here, we summarize epicardial signals and ECM components (apart from EMT signals) for the development of the myocardium and coronary vessels.

\section{Retinoic Acid}

One of the most prominent regulators of heart morphogenesis is RA signaling, for which a tightly controlled dosage is critical (Niederreither et al. 1999; D’Aniello et al. 2013). Retinaldehyde dehydrogenase 2 (Raldh2), which encodes an enzyme that catalyzes the synthesis of RA, is expressed by the developing epicardium. Deletion of Raldh2 leads to embryonic death with interrupted heart development (Niederreither et al. 1999). Deletion of retinoid $X$ receptor $\alpha(R X R \alpha)$, which is also expressed by the epicardium, disrupted CM proliferation and compact myocardium formation in mice (Sucov et al. 1994). Remarkably, a myocardial defi- 
Y. Cao et al.

ciency of $R X R \alpha$ led to normal heart formation, whereas epicardial deletion of $R X R \alpha$ recapitulated the phenotypes of global deletion, suggesting that epicardial RA signaling is necessary for heart formation (Chen et al. 1998, 2002; Merki et al. 2005). In chicken heart slice cultures, blockade of RA signaling from the epicardium inhibits CM proliferation and survival (Stuckmann et al. 2003). RA has been proposed to stimulate CM proliferation by inducing the secretion of trophic factors in the epicardium (Chen et al. 2002; Stuckmann et al. 2003; Merki et al. 2005); however, the identity of these trophic factors warrants further investigation.

\section{Fibroblast Growth Factor}

FGF is another well-known mitogen for CMs. During mouse heart development, Fgf9, Fgf16, and Fgf20 are expressed in both the endocardium and epicardium, whereas the receptors Fgfr 1 and Fgfr2 are expressed in the myocardium (Lavine et al. 2005, 2006). As mentioned above, Fgfrl and Fgfr2 are also expressed in the epicardium, suggesting interactional regulations of FGF signaling between epicardium and myocardium (Vega-Hernandez et al. 2011). Fgf9 mutant mice die at birth with a hypoplastic ventricle associated with reduced CM proliferation. Similarly, conditional knockouts of Fgfrl and Fgfr2 in the myocardium dramatically reduced $\mathrm{CM}$ proliferation and led to heart hypoplasia (Lavine et al. 2005). A follow-up study found that epicardial-myocardial FGF signaling promoted coronary growth indirectly through the activation of $\mathrm{Hh}$ signaling, which further induced VEGF expression (Lavine et al. 2006, 2008). Moreover, RA can stimulate epicardial expression of Fgf9, which shows cross talk between these pathways (Lavine et al. 2005). In addition, myocardial Fgf10 and epicardial $F g f r 1, F g f r 2 b$ signals also activate fibroblast differentiation of epicardial cells (Vega-Hernandez et al. 2011). In avian embryos, epicardial cells express Fgf1 and Fgf2 (Pennisi and Mikawa 2005). On surgical removal of the epicardium by blocking PE transition, there was reduction of myocardial proliferation and compact myocardium thickness. Further analyses suggested that decreased $F g f 2$ and Fgfr1 messenger RNA (mRNA) levels underlie this phenotype (Pennisi et al. 2003). On the other hand, in zebrafish, myocardial $f g f 17 b$ and epicardial $f g f r 2$ and $f g f r 4$ are thought to regulate the homeostatic proliferation of CMs (Wills et al. 2008). Moreover, Fgf inhibition through overexpression of a dominant-negative fgfrl blocked epicardial EMT, disrupted coronary neovascularization, and impaired heart regeneration (Lepilina et al. 2006). Evidently, FGF signaling is incorporated in epicardial-induced proliferative effects involving cross talk with other signaling pathways, including RA and Hh signaling.

Shh

In mice, epicardially expressed Shh interacts with myocardial Patched to regulate coronary vascular development (Lavine et al. 2006, 2008). Shh is one of the downstream targets of FGF signaling during coronary vessel development, and exogenous Shh can rescue the coronary plexus defect in the $F g f 9$ and $F g f r 1 / 2$ knockouts (Lavine et al. 2006). In chick embryos, blocking Shh signaling results in decreased second heart field proliferation, pulmonary atresia, and arterial pole defects (Dyer and Kirby 2009). Similarly, in zebrafish, inhibiting Shh diminishes processes relating to cell proliferation. For example, epicardial regeneration is stunted when outflow tract Shh signaling is hindered (Wang et al. 2015). Analogously, CMs display increased proliferation upon enhanced Shh signaling after heart injury (Choi et al. 2013). Although it is evident that Shh is implicated, and possibly evolutionarily conserved, in cardiac development and regeneration, the precise sources and cellular effects of Shh in the zebrafish model represents a vein of cardiac research that can be probed further.

\section{Erythropoietin}

During mouse heart development, erythropoietin (Epo) is expressed in the epicardium, and its receptor, EpoR, is expressed in the epicardium and other non-CM cells (Wu et al. 1999). Embryos deficient of either Epo or EpoR died at 
$\sim$ E13.5, displaying ventricular hypoplasia and impaired coronary vascular plexus formation. Further, chimeric mice experiments indicated that the epicardial-derived Epo influences CM proliferation in a non-cell-autonomous manner (Wu et al. 1999). Another study using heart slice primary cultures from chickens showed that blocking Epo signaling from the epicardium inhibits CM proliferation and survival (Stuckmann et al. 2003). Interestingly, this proliferation blockade can be rescued by the addition of RA. Conversely, the blocked CM proliferation following RA inhibition can be rescued by exogenous Epo, suggesting that RA and Epo signaling act in parallel to regulate CM proliferation (Stuckmann et al. 2003). Further analysis proposed that Epo or RA signaling induced soluble mitogens from the epicardium to allow for CM proliferation, although the exact nature of these mitogens is still unknown (Stuckmann et al. 2003).

\section{Vascular Endothelial Growth Factor}

VEGF is an essential regulator of endothelial cell differentiation and vessel development (Kapuria et al. 2018). In mice, myocardial-derived VEGFA interacts with the receptor VEGFR2 in endocardial cells to regulate coronary plexus formation ( $\mathrm{Wu}$ et al. 2012). Chen et al. found that mouse embryonic epicardial cells expressed VEGFC, which interacts with VEGFR2 and VEGFR3 in the cardiac endothelial cells. Additionally, deletion of $V e g f c$ dramatically inhibited dorsal and lateral coronary artery growth without affecting vessels on the ventral side (Chen et al. 2014). In contrast, zebrafish vegfaa, the homolog of mammalian Vegfa, is expressed in the epicardium, and vegfaa overexpression enhances coronary angiogenesis and epicardial expansion and results in CM hyperplasia (Karra et al. 2018). The controlled regulation of Vegfaa may warrant further analysis as a potential therapeutic target for cardiac regeneration.

\section{Insulin-Like Growth Factor}

Mouse insulin-like growth factor 2 (IGF2) is reported to be secreted by epicardial cells to pro- mote CM proliferation during heart development (Li et al. 2011). Global knockout of Igf2 or CM-specific knockout of the receptors Igflr and Ins $r$ both reduced CM proliferation and impaired ventricular development (Li et al. 2011). In zebrafish, the pharmacological inhibition of Igf signaling or the overexpression of a dominant-negative version of the receptor Igf1 ra inhibited CM proliferation and reduced embryonic CM quantity (Huang et al. 2013). Although the source of Igf signals during zebrafish heart development is unknown, $i g f 2 b$ was detected in both the endocardium and epicardium of the postinjury wound region at a time that coincides with CM proliferation (Huang et al. 2013).

\section{Notch}

Notch signaling has been reported to regulate SMC differentiation of epicardial progeny (del Monte et al. 2011; Grieskamp et al. 2011). Using a Tbx18-Cre line, Grieskamp et al. found that epicardial-specific deletion of the intracellular mediator of Notch, Rbpj, impaired the differentiation of vSMCs in mice; whereas overexpressing the Notch1 intracellular domain (NICD) in the epicardium induced premature SMC differentiation and prevented coronary angiogenesis. Moreover, the authors further showed that Notch acts upstream of TGF- $\beta$ and PDGF signaling in SMC differentiation (Grieskamp et al. 2011). In another study, epicardial-specific Notch1 ablation using a Wt1-Cre line both disrupted coronary artery differentiation and reduced CM proliferation (del Monte et al. 2011). Meanwhile, ectopic Notch1 activation in the epicardial lineage caused thinning of epicardium and ventricular myocardium, although SMC differentiation was not assessed in this setting (del Monte et al. 2011).

Wnt

Epicardial-specific deletion of $\beta$-catenin in mice caused death between E15.5 and birth (Zamora et al. 2007). The mutant heart displayed signs of reduced CM proliferation, impaired epicardial EMT, and blunted coronary artery formation. Because junctional $\beta$-catenin regulates epicardi- 
Y. Cao et al.

al EMT (Wu et al. 2010), it is unclear how Wnt/ $\beta$-catenin signaling functions in this setting. Also, the source of Wnt ligands during coronary development is unclear.

\section{Extracellular Matrix Components}

ECM components are extracellular molecules secreted by cells that provide structural support and biochemical cues to the surrounding cells (Frantz et al. 2010). The ECM component fibronectin (Fn) was reported to be critical for heart morphogenesis in both the mouse and zebrafish (George et al. 1997; Trinh and Stainier 2004). Epicardial cells and their derived fibroblasts are the primary sources of ECM during heart development. Ieda et al. (2009) found that embryonic cardiac fibroblasts induced CM proliferation in a coculture system through the secretion of Fn and collagen, in addition to heparin-binding EGF-like growth factor (HBEGF). This proliferative effect was exerted through myocardial $\beta 1$-integrin (Sengbusch et al. 2002), which when deleted in CMs has been shown to impair myocardial proliferation and ventricular compaction (Ieda et al. 2009). Also, as mentioned above, deletion of $\alpha 4$-integrin in mice disrupts epicardium formation during development by impairing epicardial cell attachment and migration (Sengbusch et al. 2002). During heart regeneration, there is intensive remodeling of ECM components, including Fn, collagen XII, tenascin-C, and HA (Mercer et al. 2013; Wang et al. 2013; Marro et al. 2016). Overall, epicardial ECM deposition may be manipulated to facilitate heart regeneration.

\section{CONCLUDING REMARKS}

The epicardium and its progeny constitute an essential part of heart development by simultaneously serving as a source of progenitor cells and as a signaling center. In terms of heart regeneration, the epicardium responds to injury through the reactivation of developmental signals across species. It is noteworthy that there could be regeneration-specific pathways in the injured adult heart that are distinct from the signaling in the embryonic heart, which warrant further investigation. Despite decades of study, there are still outstanding questions to be addressed in the field of epicardial biology, the answers to which could inspire new therapeutic strategies for heart diseases. The complete lineages of epicardial cells, mechanisms of lineage commitment, and strategies to activate the epicardium after cardiac injury are among the highest research priorities. Altogether, more refined lineage-tracing tools including next-generation sequencing-based, single-cell fate-mapping (Briggs et al. 2018; Farrell et al. 2018; Wagner et al. 2018) and dual-recombinase genetic systems (He et al. 2017), together with an explant culture approach and human stem cell-derived epicardial cells will ultimately move the field of epicardial research forward.

\section{ACKNOWLEDGMENTS}

We thank G. Pitt and R. Karra for helpful feedback. We apologize to our colleagues whose work was not discussed owing to space limitations. J.C. is supported by the American Heart Association Career Development Award (18CDA34110108) and Weill Cornell Medical College start-up fund.

\section{REFERENCES}

Acharya A, Baek ST, Huang G, Eskiocak B, Goetsch S, Sung CY, Banfi S, Sauer MF, Olsen GS, Duffield JS, et al. 2012. The bHLH transcription factor Tcf21 is required for lineage-specific EMT of cardiac fibroblast progenitors. Development 139: 2139-2149. doi:10.1242/dev.079970

Ali SR, Ranjbarvaziri S, Talkhabi M, Zhao P, Subat A, Hojjat A, Kamran P, Muller AM, Volz KS, Tang Z, et al. 2014 Developmental heterogeneity of cardiac fibroblasts does not predict pathological proliferation and activation. Circ Res 115: 625-635. doi:10.1161/CIRCRESAHA.115 .303794

Andrés-Delgado L, Ernst A, Galardi-Castilla M, Bazaga D, Peralta M, Münch J, González-Rosa JM, Marques I, Tessadori F, de la Pompa JL, et al. 2019. Actin dynamics and the Bmp pathway drive apical extrusion of proepicardial cells. Development 146: dev174961. doi:10.1242/ dev.174961

Antonopoulos AS, Antoniades C. 2017. The role of epicardial adipose tissue in cardiac biology: classic concepts and emerging roles. J Physiol 595: 3907-3917. doi:10.1113/ JP273049

Austin AF, Compton LA, Love JD, Brown CB, Barnett JV. 2008. Primary and immortalized mouse epicardial cells 
undergo differentiation in response to TGF $\beta$. Dev Dyn 237: 366-376. doi:10.1002/dvdy.21421

Balmer GM, Bollini S, Dubé KN, Martinez-Barbera JP, Williams O, Riley PR. 2014. Dynamic haematopoietic cell contribution to the developing and adult epicardium. Nat Commun 5: 4054. doi:10.1038/ncomms5054

Bollini S, Vieira JM, Howard S, Dubè KN, Balmer GM, Smart N, Riley PR. 2014. Re-activated adult epicardial progenitor cells are a heterogeneous population molecularly distinct from their embryonic counterparts. Stem Cells Dev 23: 1719-1730. doi:10.1089/scd.2014.0019

Braitsch CM, Combs MD, Quaggin SE, Yutzey KE. 2012. Pod1/Tcf 21 is regulated by retinoic acid signaling and inhibits differentiation of epicardium-derived cells into smooth muscle in the developing heart. Dev Biol 368: 345-357. doi:10.1016/j.ydbio.2012.06.002

Braitsch CM, Kanisicak O, van Berlo JH, Molkentin JD, Yutzey KE. 2013. Differential expression of embryonic epicardial progenitor markers and localization of cardiac fibrosis in adult ischemic injury and hypertensive heart disease. J Mol Cell Cardiol 65: 108-119. doi:10.1016/j .yjmcc.2013.10.005

Briggs JA, Weinreb C, Wagner DE, Megason S, Peshkin L, Kirschner MW, Klein AM. 2018. The dynamics of gene expression in vertebrate embryogenesis at single-cell resolution. Science 360: eaar5780. doi:10.1126/science .aar5780

Cai CL, Martin JC, Sun Y, Cui L, Wang L, Ouyang K, Yang L, Bu L, Liang X, Zhang X, et al. 2008. A myocardial lineage derives from Tbx18 epicardial cells. Nature 454: 104-108. doi:10.1038/nature06969

Cano E, Carmona R, Ruiz-Villalba A, Rojas A, Chau YY, Wagner KD, Wagner N, Hastie ND, Muñoz-Chápuli R, Pérez-Pomares JM. 2016. Extracardiac septum transversum/proepicardial endothelial cells pattern embryonic coronary arterio-venous connections. Proc Natl Acad Sci 113: 656-661. doi:10.1073/pnas.1509834113

Cao J, Poss KD. 2018. The epicardium as a hub for heart regeneration. Nat Rev Cardiol 15: 631-647. doi:10.1038/ s41569-018-0046-4

Cao J, Navis A, Cox BD, Dickson AL, Gemberling M, Karra R, Bagnat M, Poss KD. 2016. Single epicardial cell transcriptome sequencing identifies Caveolin 1 as an essential factor in zebrafish heart regeneration. Development 143: 232-243. doi:10.1242/dev.130534

Chen J, Kubalak SW, Chien KR. 1998. Ventricular muscle-restricted targeting of the $R X R \alpha$ gene reveals a non-cell-autonomous requirement in cardiac chamber morphogenesis. Development 125: 1943-1949.

Chen T, Chang TC, Kang JO, Choudhary B, Makita T, Tran CM, Burch JB, Eid H, Sucov HM. 2002. Epicardial induction of fetal cardiomyocyte proliferation via a retinoic acid-inducible trophic factor. Dev Biol 250: 198-207. doi:10.1006/dbio.2002.0796

Chen HI, Sharma B, Akerberg BN, Numi HJ, Kivela R, Saharinen P, Aghajanian H, McKay AS, Bogard PE, Chang $\mathrm{AH}$, et al. 2014. The sinus venosus contributes to coronary vasculature through VEGFC-stimulated angiogenesis. Development 141: 4500-4512. doi:10.1242/dev .113639

Choi WY, Gemberling M, Wang J, Holdway JE, Shen MC, Karlstrom RO, Poss KD. 2013. In vivo monitoring of cardiomyocyte proliferation to identify chemical modifiers of heart regeneration. Development 140: 660-666. doi:10.1242/dev.088526

Chong JJ, Chandrakanthan V, Xaymardan M, Asli NS, Li J, Ahmed I, Heffernan C, Menon MK, Scarlett CJ, Rashidianfar A, et al. 2011. Adult cardiac-resident MSC-like stem cells with a proepicardial origin. Cell Stem Cell 9: 527-540. doi:10.1016/j.stem.2011.10.002

Christoffels VM, Grieskamp T, Norden J, Mommersteeg MT, Rudat C, Kispert A. 2009. Tbx18 and the fate of epicardial progenitors. Nature 458: E8-E9. discussion E9-E10. doi:10.1038/nature07916

Combs MD, Braitsch CM, Lange AW, James JF, Yutzey KE. 2011. NFATC1 promotes epicardium-derived cell invasion into myocardium. Development 138: 1747-1757. doi:10.1242/dev.060996

Compton LA, Potash DA, Mundell NA, Barnett JV. 2006. Transforming growth factor- $\beta$ induces loss of epithelial character and smooth muscle cell differentiation in epicardial cells. Dev Dyn 235: 82-93. doi:10.1002/dvdy .20629

Craig EA, Austin AF, Vaillancourt RR, Barnett JV, Camenisch TD. 2010. TGFß2-mediated production of hyaluronan is important for the induction of epicardial cell differentiation and invasion. Exp Cell Res 316: 33973405. doi:10.1016/j.yexcr.2010.07.006

D’Aniello E, Rydeen AB, Anderson JL, Mandal A, Waxman JS. 2013. Depletion of retinoic acid receptors initiates a novel positive feedback mechanism that promotes teratogenic increases in retinoic acid. PLoS Genet 9: e1003689. doi:10.1371/journal.pgen.1003689

del Monte G, Casanova JC, Guadix JA, MacGrogan D, Burch JB, Pérez-Pomares JM, de la Pompa JL. 2011. Differential Notch signaling in the epicardium is required for cardiac inflow development and coronary vessel morphogenesis. Circ Res 108: 824-836. doi:10.1161/CIRCRESAHA.110 .229062

Dettman RW, Denetclaw WJ, Ordahl CP, Bristow J. 1998. Common epicardial origin of coronary vascular smooth muscle, perivascular fibroblasts, and intermyocardial fibroblasts in the avian heart. Dev Biol 193: 169-181. doi:10 $.1006 /$ dbio.1997.8801

Dettman RW, Pae SH, Morabito C, Bristow J. 2003. Inhibition of $\alpha 4$-integrin stimulates epicardial-mesenchymal transformation and alters migration and cell fate of epicardially derived mesenchyme. Dev Biol 257: 315-328. doi:10.1016/S0012-1606(03)00064-2

Dyer LA, Kirby ML. 2009. Sonic hedgehog maintains proliferation in secondary heart field progenitors and is required for normal arterial pole formation. Dev Biol 330: 305-317. doi:10.1016/j.ydbio.2009.03.028

Farrell JA, Wang Y, Riesenfeld SJ, Shekhar K, Regev A, Schier AF. 2018. Single-cell reconstruction of developmental trajectories during zebrafish embryogenesis. Science 360: eaar3131. doi:10.1126/science.aar3131

Fransen ME, Lemanski LF. 1990. Epicardial development in the axolotl, Ambystoma mexicanum. Anat Rec 226: 228 236. doi:10.1002/ar.1092260212

Frantz C, Stewart KM, Weaver VM. 2010. The extracellular matrix at a glance. J Cell Sci 123: 4195-4200. doi:10.1242/ jcs. 023820 
Y. Cao et al.

Gemberling M, Karra R, Dickson AL, Poss KD. 2015. Nrg1 is an injury-induced cardiomyocyte mitogen for the endogenous heart regeneration program in zebrafish. eLife 4: e05871. doi:10.7554/eLife.05871

George EL, Baldwin HS, Hynes RO. 1997. Fibronectins are essential for heart and blood vessel morphogenesis but are dispensable for initial specification of precursor cells. Blood 90: 3073-3081.

Gittenberger-de Groot AC, Vrancken Peeters MP, Mentink MM, Gourdie RG, Poelmann RE. 1998. Epicardium-derived cells contribute a novel population to the myocardial wall and the atrioventricular cushions. Circ Res 82: 1043-1052. doi:10.1161/01.RES.82.10.1043

González-Rosa JM, Martin V, Peralta M, Torres M, Mercader N. 2011. Extensive scar formation and regression during heart regeneration after cryoinjury in zebrafish. Development 138: 1663-1674. doi:10.1242/dev.060897

González-Rosa JM, Peralta M, Mercader N. 2012. Pan-epicardial lineage tracing reveals that epicardium derived cells give rise to myofibroblasts and perivascular cells during zebrafish heart regeneration. Dev Biol 370: 173-186. doi:10.1016/j.ydbio.2012.07.007

Grieskamp T, Rudat C, Lüdtke TH, Norden J, Kispert A. 2011. Notch signaling regulates smooth muscle differentiation of epicardium-derived cells. Circ Res 108: 813823. doi:10.1161/CIRCRESAHA.110.228809

Guadix JA, Carmona R, Munoz-Chapuli R, Pérez-Pomares JM. 2006. In vivo and in vitro analysis of the vasculogenic potential of avian proepicardial and epicardial cells. Dev Dyn 235: 1014-1026. doi:10.1002/dvdy.20685

He L, Li Y, Li Y, Pu W, Huang X, Tian X, Wang Y, Zhang H, Liu Q, Zhang L, et al. 2017. Enhancing the precision of genetic lineage tracing using dual recombinases. Nat Med 23: 1488-1498. doi:10.1038/nm.4437

Hirakow R. 1992. Epicardial formation in staged human embryos. Kaibogaku Zasshi 67: 616-622.

Hirose T, Karasawa M, Sugitani Y, Fujisawa M, Akimoto K, Ohno S, Noda T. 2006. PAR3 is essential for cyst-mediated epicardial development by establishing apical cortical domains. Development 133: 1389-1398. doi:10.1242/ dev.02294

Huang GN, Thatcher JE, McAnally J, Kong Y, Qi X, Tan W, DiMaio JM, Amatruda JF, Gerard RD, Hill JA, et al. 2012. C/EBP transcription factors mediate epicardial activation during heart development and injury. Science 338: 15991603. doi:10.1126/science. 1229765

Huang Y, Harrison MR, Osorio A, Kim J, Baugh A, Duan C, Sucov HM, Lien CL. 2013. Igf signaling is required for cardiomyocyte proliferation during zebrafish heart development and regeneration. PLoS ONE 8: e67266. doi:10 .1371/journal.pone.0067266

Ieda M, Tsuchihashi T, Ivey KN, Ross RS, Hong TT, Shaw RM, Srivastava D. 2009. Cardiac fibroblasts regulate myocardial proliferation through $\beta 1$ integrin signaling. Dev Cell 16: 233-244. doi:10.1016/j.devcel.2008.12.007

Ishii Y, Garriock RJ, Navetta AM, Coughlin LE, Mikawa T. 2010. BMP signals promote proepicardial protrusion necessary for recruitment of coronary vessel and epicardial progenitors to the heart. Dev Cell 19: 307-316. doi:10 .1016/j.devcel.2010.07.017

Ito K, Morioka M, Kimura S, Tasaki M, Inohaya K, Kudo A. 2014. Differential reparative phenotypes between zebra- fish and medaka after cardiac injury. Dev Dyn 243: 1106 1115. doi:10.1002/dvdy.24154

Iyer D, Gambardella L, Bernard WG, Serrano F, Mascetti VL, Pedersen RA, Talasila A, Sinha S. 2015. Robust derivation of epicardium and its differentiated smooth muscle cell progeny from human pluripotent stem cells. Development 142: $1528-1541$. doi:10.1242/dev.119271

Jahr M, Schlueter J, Brand T, Männer J. 2008. Development of the proepicardium in Xenopus laevis. Dev Dyn 237: 3088-3096. doi:10.1002/dvdy.21713

Kapuria S, Yoshida T, Lien CL. 2018. Coronary vasculature in cardiac development and regeneration. J Cardiovasc Dev Dis 5: E59. doi: 10.3390/jcdd5040059

Karra R, Foglia MJ, Choi WY, Belliveau C, DeBenedittis P, Poss KD. 2018. Vegfaa instructs cardiac muscle hyperplasia in adult zebrafish. Proc Natl Acad Sci 115: 8805-8810. doi:10.1073/pnas.1722594115

Katz TC, Singh MK, Degenhardt K, Rivera-Feliciano J, Johnson RL, Epstein JA, Tabin CJ. 2012. Distinct compartments of the proepicardial organ give rise to coronary vascular endothelial cells. Dev Cell 22: 639-650. doi:10 .1016/j.devcel.2012.01.012

Kikuchi K, Gupta V, Wang J, Holdway JE, Wills AA, Fang Y, Poss KD. 2011. $t c f 21^{+}$epicardial cells adopt non-myocardial fates during zebrafish heart development and regeneration. Development 138: 2895-2902. doi:10.1242/dev .067041

Komiyama M, Ito K, Shimada Y. 1987. Origin and development of the epicardium in the mouse embryo. Anat Embryol (Berl) 176: 183-189. doi:10.1007/BF00310051

Kurkiewicz TO. 1909. Histogenezie miesna sur cowego zwierzat kregowych-Zur Histogenese des Herzmuskels der Wilbertiere. [The histogenesis of the heart muscle of vertebrates.] Bull Int Acad Sci Cracov 148-191.

Kwee L, Baldwin HS, Shen HM, Stewart CL, Buck C, Buck CA, Labow MA. 1995. Defective development of the embryonic and extraembryonic circulatory systems in vascular cell adhesion molecule (VCAM-1) deficient mice. Development 121: 489-503.

Lane EB, Hogan BL, Kurkinen M, Garrels JI. 1983. Co-expression of vimentin and cytokeratins in parietal endoderm cells of early mouse embryo. Nature 303: 701-704 doi:10.1038/303701a0

Lavine KJ, Yu K, White AC, Zhang X, Smith C, Partanen J, Ornitz DM. 2005. Endocardial and epicardial derived FGF signals regulate myocardial proliferation and differentiation in vivo. Dev Cell 8: 85-95. doi:10.1016/j.devcel .2004 .12 .002

Lavine KJ, White AC, Park C, Smith CS, Choi K, Long F, Hui CC, Ornitz DM. 2006. Fibroblast growth factor signals regulate a wave of Hedgehog activation that is essential for coronary vascular development. Genes Dev 20: 16511666. doi:10.1101/gad.1411406

Lavine KJ, Long F, Choi K, Smith C, Ornitz DM. 2008. Hedgehog signaling to distinct cell types differentially regulates coronary artery and vein development. Development 135: 3161-3171. doi:10.1242/dev.019919

Lepilina A, Coon AN, Kikuchi K, Holdway JE, Roberts RW, Burns CG, Poss KD. 2006. A dynamic epicardial injury response supports progenitor cell activity during zebrafish heart regeneration. Cell 127: 607-619. doi:10.1016/j .cell.2006.08.052 
Leung OM, Zhou B, Lui KO. 2016. Vascular development and regeneration in the mammalian heart. J Cardiovasc Dev Dis 3: E23. doi:10.3390/jcdd3020023

Li P, Cavallero S, Gu Y, Chen TH, Hughes J, Hassan AB, Bruning JC, Pashmforoush M, Sucov HM. 2011. IGF signaling directs ventricular cardiomyocyte proliferation during embryonic heart development. Development 138: 1795-1805. doi:10.1242/dev.054338

Li J, Miao L, Zhao C, Shaikh Qureshi WM, Shieh D, Guo H, Lu Y, Hu S, Huang A, Zhang L, et al. 2017. CDC42 is required for epicardial and pro-epicardial development by mediating FGF receptor trafficking to the plasma membrane. Development 144: 1635-1647. doi:10.1242/ dev. 147173

Lie-Venema H, van den Akker NM, Bax NA, Winter EM, Maas S, Kekarainen T, Hoeben RC, deRuiter MC, Poelmann RE, Gittenberger-de Groot AC. 2007. Origin, fate, and function of epicardium-derived cells (EPDCs) in normal and abnormal cardiac development. ScientificWorldJournal 7: 1777-1798. doi:10.1100/tsw.2007.294

Limana F, Zacheo A, Mocini D, Mangoni A, Borsellino G, Diamantini A, De Mori R, Battistini L, Vigna E, Santin $\mathrm{M}$, et al. 2007. Identification of myocardial and vascular precursor cells in human and mouse epicardium. Circ Res 101: 1255-1265. doi:10.1161/CIRCRESAHA.107.150755

Limana F, Capogrossi MC, Germani A. 2011. The epicardium in cardiac repair: From the stem cell view. Pharmacol Ther 129: 82-96. doi:10.1016/j.pharmthera.2010.09.002

Liu J, Stainier DY. 2010. Tbx5 and Bmp signaling are essential for proepicardium specification in zebrafish. Circ Res 106: 1818-1828. doi:10.1161/CIRCRESAHA.110.217950

Liu Q, Huang X, Oh JH, Lin RZ, Duan S, Yu Y, Yang R, Qiu J, Melero-Martin JM, Pu WT, et al. 2014. Epicardium-to-fat transition in injured heart. Cell Res 24: 1367-1369. doi:10 $.1038 / \mathrm{cr} .2014 .125$

Liu Q, Zhang H, Tian X, He L, Huang X, Tan Z, Yan Y, Evans SM, Wythe JD, Zhou B. 2016. Smooth muscle origin of postnatal 2nd CVP is pre-determined in early embryo. Biochem Biophys Res Commun 471: 430-436. doi:10 $.1016 /$ j.bbrc.2016.02.062

Manasek FJ. 1968. Embryonic development of the heart. I: A light and electron microscopic study of myocardial development in the early chick embryo. J Morphol 125: 329365. doi:10.1002/jmor.1051250306

Manasek FJ. 1969. Embryonic development of the heart. II: Formation of the epicardium. J Embryol Exp Morphol 22: 333-348.

Manner J. 1992. The development of pericardial villi in the chick embryo. Anat Embryol (Berl) 186: 379-385. doi:10 1007/BF00185988

Manner J. 1993. Experimental study on the formation of the epicardium in chick embryos. Anat Embryol (Berl) 187: 281-289. doi:10.1007/BF00195766

Manner J. 1999. Does the subepicardial mesenchyme contribute myocardioblasts to the myocardium of the chick embryo heart? A quail-chick chimera study tracing the fate of the epicardial primordium. Anat Rec 255: 212226. doi:10.1002/(SICI)1097-0185(19990601)255:2<212 :AID-AR11>3.0.CO;2-X

Marro J, Pfefferli C, de Preux Charles AS, Bise T, Jaźwinska A. 2016. Collagen XII contributes to epicardial and connective tissues in the zebrafish heart during ontogenesis and regeneration. PLoS ONE 11: e0165497. doi:10.1371/ journal.pone. 0165497

Martínez-Estrada OM, Lettice LA, Essafi A, Guadix JA, Slight J, Velecela V, Hall E, Reichmann J, Devenney PS, Hohenstein P, et al. 2010. Wt1 is required for cardiovascular progenitor cell formation through transcriptional control of Snail and E-cadherin. Nat Genet 42: 89-93. doi:10.1038/ng.494

Masters M, Riley PR. 2014. The epicardium signals the way towards heart regeneration. Stem Cell Res 13: 683-692. doi:10.1016/j.scr.2014.04.007

Mercer SE, Odelberg SJ, Simon HG. 2013. A dynamic spatiotemporal extracellular matrix facilitates epicardial-mediated vertebrate heart regeneration. Dev Biol 382: 457469. doi:10.1016/j.ydbio.2013.08.002

Merki E, Zamora M, Raya A, Kawakami Y, Wang J, Zhang X, Burch J, Kubalak SW, Kaliman P, Izpisua Belmonte JC, et al. 2005. Epicardial retinoid X receptor $\alpha$ is required for myocardial growth and coronary artery formation. Proc Natl Acad Sci 102: 18455-18460. doi:10.1073/pnas .0504343102

Mikawa T, Fischman DA. 1992. Retroviral analysis of cardiac morphogenesis: Discontinuous formation of coronary vessels. Proc Natl Acad Sci 89: 9504-9508. doi:10.1073/ pnas.89.20.9504

Mikawa T, Gourdie RG. 1996. Pericardial mesoderm generates a population of coronary smooth muscle cells migrating into the heart along with ingrowth of the epicardial organ. Dev Biol 174: 221-232. doi:10.1006/dbio.1996 .0068

Missinato MA, Tobita K, Romano N, Carroll JA, Tsang M. 2015. Extracellular component hyaluronic acid and its receptor Hmmr are required for epicardial EMT during heart regeneration. Cardiovasc Res 107: 487-498. doi:10 $.1093 / \mathrm{cvr} / \mathrm{cvv} 190$

Molin DG, Bartram U, Van der Heiden K, Van Iperen L, Speer CP, Hierck BP, Poelmann RE, Gittenberger-deGroot AC. 2003. Expression patterns of Tgf $\beta 1-3$ associate with myocardialisation of the outflow tract and the development of the epicardium and the fibrous heart skeleton. Dev Dyn 227: 431-444. doi:10.1002/dvdy.10314

Moore-Morris T, Guimaraes-Camboa N, Banerjee I, Zambon AC, Kisseleva T, Velayoudon A, Stallcup WB, Gu Y, Dalton ND, Cedenilla M, et al. 2014. Resident fibroblast lineages mediate pressure overload-induced cardiac fibrosis. J Clin Invest 124: 2921-2934. doi:10.1172/JCI74783

Moore-Morris T, Guimarães-Camboa N, Yutzey KE, Pucéat M, Evans SM. 2015. Cardiac fibroblasts: From development to heart failure. J Mol Med (Berl) 93: 823-830. doi:10.1007/s00109-015-1314-y

Moore-Morris T, Cattaneo P, Puceat M, Evans SM. 2016. Origins of cardiac fibroblasts. J Mol Cell Cardiol 91: 15. doi:10.1016/j.yjmcc.2015.12.031

Morabito CJ, Dettman RW, Kattan J, Collier JM, Bristow J. 2001. Positive and negative regulation of epicardial-mesenchymal transformation during avian heart development. Dev Biol 234: 204-215. doi:10.1006/dbio.2001 .0254

Nahirney PC, Mikawa T, Fischman DA. 2003. Evidence for an extracellular matrix bridge guiding proepicardial cell migration to the myocardium of chick embryos. Dev Dyn 227: 511-523. doi:10.1002/dvdy.10335 
Y. Cao et al.

Nesbitt T, Lemley A, Davis J, Yost MJ, Goodwin RL, Potts JD. 2006. Epicardial development in the rat: A new perspective. Microsc Microanal 12: 390-398. doi:10.1017/ S1431927606060533

Niederreither K, Subbarayan V, Dollé P, Chambon P. 1999. Embryonic retinoic acid synthesis is essential for early mouse post-implantation development. Nat Genet 21: 444-448. doi:10.1038/7788

Olivey HE, Mundell NA, Austin AF, Barnett JV. 2006. Transforming growth factor- $\beta$ stimulates epithelial-mesenchymal transformation in the proepicardium. Dev Dyn 235: 50-59. doi:10.1002/dvdy.20593

Pennisi DJ, Mikawa T. 2005. Normal patterning of the coronary capillary plexus is dependent on the correct transmural gradient of FGF expression in the myocardium. Dev Biol 279: 378-390. doi:10.1016/j.ydbio.2004.12.028

Pennisi DJ, Ballard VL, Mikawa T. 2003. Epicardium is required for the full rate of myocyte proliferation and levels of expression of myocyte mitogenic factors FGF2 and its receptor, FGFR-1, but not for transmural myocardial patterning in the embryonic chick heart. Dev Dyn 228: 161172. doi: $10.1002 /$ dvdy. 10360

Peralta M, Steed E, Harlepp S, González-Rosa JM, Monduc F, Ariza-Cosano A, Cortés A, Rayon T, Gómez-Skarmeta JL, Zapata A, et al. 2013. Heartbeat-driven pericardiac fluid forces contribute to epicardium morphogenesis. Curr Biol 23: 1726-1735. doi:10.1016/j.cub.2013.07.005

Perez-Pomares JM, Carmona R, González-Iriarte M, Atencia G, Wessels A, Munoz-Chapuli R. 2002a. Origin of coronary endothelial cells from epicardial mesothelium in avian embryos. Int J Dev Biol 46: 1005-1013.

Pérez-Pomares JM, Phelps A, Sedmerova M, Carmona R, González-Iriarte M, Muñoz-Chápuli R, Wessels A 2002b. Experimental studies on the spatiotemporal expression of WT1 and RALDH2 in the embryonic avian heart: A model for the regulation of myocardial and valvuloseptal development by epicardially derived cells (EPDCs). Dev Biol 247: 307-326. doi:10.1006/dbio.2002 .0706

Perner B, Englert C, Bollig F. 2007. The Wilms tumor genes $w t 1 a$ and $w t 1 b$ control different steps during formation of the zebrafish pronephros. Dev Biol 309: 87-96. doi:10 .1016/j.ydbio.2007.06.022

Plavicki JS, Hofsteen P, Yue MS, Lanham KA, Peterson RE, Heideman W. 2014. Multiple modes of proepicardial cell migration require heartbeat. $B M C$ Dev Biol 14: 18. doi:10 $.1186 / 1471-213 X-14-18$

Riley PR. 2012. An epicardial floor plan for building and rebuilding the mammalian heart. Curr Top Dev Biol 100: 233-251. doi:10.1016/B978-0-12-387786-4.00007-5

Risebro CA, Vieira JM, Klotz L, Riley PR. 2015. Characterisation of the human embryonic and foetal epicardium during heart development. Development 142: 3630-3636. doi:10.1242/dev.127621

Rodgers LS, Lalani S, Runyan RB, Camenisch TD. 2008. Differential growth and multicellular villi direct proepicardial translocation to the developing mouse heart. Dev Dyn 237: 145-152. doi:10.1002/dvdy.21378

Rudat C, Kispert A. 2012. Wt1 and epicardial fate mapping. Circ Res 111: 165-169. doi:10.1161/CIRCRESAHA.112 .273946
Schlueter J, Männer J, Brand T. 2006. BMP is an important regulator of proepicardial identity in the chick embryo. Dev Biol 295: 546-558. doi:10.1016/j.ydbio.2006.03.036

Schnabel K, Wu CC, Kurth T, Weidinger G. 2011. Regeneration of cryoinjury induced necrotic heart lesions in zebrafish is associated with epicardial activation and cardiomyocyte proliferation. PLOS ONE 6: e18503. doi:10 .1371/journal.pone.0018503

Sengbusch JK, He W, Pinco KA, Yang JT. 2002. Dual functions of $\alpha 4 \beta 1$ integrin in epicardial development: Initial migration and long-term attachment. J Cell Biol 157: 873882. doi: $10.1083 /$ jcb. 200203075

Serluca FC. 2008. Development of the proepicardial organ in the zebrafish. Dev Biol 315: 18-27. doi:10.1016/j.ydbio .2007.10.007

Simões FC, Riley PR. 2018. The ontogeny, activation and function of the epicardium during heart development and regeneration. Development 145: dev155994. doi:10 $.1242 /$ dev.155994

Singh A, Ramesh S, Cibi DM, Yun LS, Li J, Li L, Manderfield LJ, Olson EN, Epstein JA, Singh MK. 2016. Hippo signaling mediators Yap and Taz are required in the epicardium for coronary vasculature development. Cell Rep 15: 13841393. doi:10.1016/j.celrep.2016.04.027

Smart N, Risebro CA, Melville AA, Moses K, Schwartz RJ, Chien KR, Riley PR. 2007. Thymosin $\beta 4$ induces adult epicardial progenitor mobilization and neovascularization. Nature 445: 177-182. doi:10.1038/nature05383

Smart N, Bollini S, Dube KN, Vieira JM, Zhou B, Davidson S, Yellon D, Riegler J, Price AN, Lythgoe MF, et al. 2011. De novo cardiomyocytes from within the activated adult heart after injury. Nature 474: 640-644. doi:10.1038/na ture10188

Sridurongrit S, Larsson J, Schwartz R, Ruiz-Lozano P, Kaartinen V. 2008. Signaling via the Tgf- $\beta$ type I receptor Alk 5 in heart development. Dev Biol 322: 208-218. doi:10 $.1016 /$ j.ydbio.2008.07.038

Stuckmann I, Evans S, Lassar AB. 2003. Erythropoietin and retinoic acid, secreted from the epicardium, are required for cardiac myocyte proliferation. Dev Biol 255: 334-349. doi:10.1016/S0012-1606(02)00078-7

Sucov HM, Dyson E, Gumeringer CL, Price J, Chien KR, Evans RM. 1994. RXR $\alpha$ mutant mice establish a genetic basis for vitamin A signaling in heart morphogenesis. Genes Dev 8: 1007-1018. doi:10.1101/gad.8.9.1007

Torlopp A, Schlueter J, Brand T. 2010. Role of fibroblast growth factor signaling during proepicardium formation in the chick embryo. Dev Dyn 239: 2393-2403. doi:10 $.1002 /$ dvdy.22384

Tournoij E, Weber GJ, Akkerman JW, de Groot PG, Zon LI, Moll FL, Schulte-Merker S. 2010. Mlck1a is expressed in zebrafish thrombocytes and is an essential component of thrombus formation. J Thromb Haemost 8: 588-595. doi:10.1111/j.1538-7836.2009.03721.x

Tran JR, Zheng X, Zheng Y. 2016. Lamin-B1 contributes to the proper timing of epicardial cell migration and function during embryonic heart development. Mol Biol Cell 27: 3956-3963. doi:10.1091/mbc.e16-06-0462

Trembley MA, Velasquez LS, de Mesy Bentley KL, Small EM. 2015. Myocardin-related transcription factors control the motility of epicardium-derived cells and the maturation 
of coronary vessels. Development 142: 21-30. doi:10 $.1242 /$ dev. 116418

Trinh LA, Stainier DY. 2004. Fibronectin regulates epithelial organization during myocardial migration in zebrafish. Dev Cell 6: 371-382. doi:10.1016/S1534-5807(04) 00063-2

van Wijk B, van den Berg G, Abu-Issa R, Barnett P, van der Velden S, Schmidt M, Ruijter JM, Kirby ML, Moorman AF, van den Hoff MJ. 2009. Epicardium and myocardium separate from a common precursor pool by crosstalk between bone morphogenetic protein- and fibroblast growth factor-signaling pathways. Circ Res 105: 431441. doi:10.1161/CIRCRESAHA.109.203083

Vega-Hernandez M, Kovacs A, De Langhe S, Ornitz DM. 2011. FGF10/FGFR2b signaling is essential for cardiac fibroblast development and growth of the myocardium. Development 138: 3331-3340. doi:10.1242/dev.064410

von Gise A, Zhou B, Honor LB, Ma Q, Petryk A, Pu WT. 2011. WT1 regulates epicardial epithelial to mesenchymal transition through $\beta$-catenin and retinoic acid signaling pathways. Dev Biol 356: 421-431. doi:10.1016/j.ydbio .2011 .05 .668

Wada AM, Smith TK, Osler ME, Reese DE, Bader DM. 2003. Epicardial/mesothelial cell line retains vasculogenic potential of embryonic epicardium. Circ Res 92: 525-531. doi:10.1161/01.RES.0000060484.11032.0B

Wagner DE, Weinreb C, Collins ZM, Briggs JA, Megason SG, Klein AM. 2018. Single-cell mapping of gene expression landscapes and lineage in the zebrafish embryo. Science 360: 981-987. doi:10.1126/science.aar4362

Wang J, Karra R, Dickson AL, Poss KD. 2013. Fibronectin is deposited by injury-activated epicardial cells and is necessary for zebrafish heart regeneration. Dev Biol 382: 427435. doi:10.1016/j.ydbio.2013.08.012

Wang J, Cao J, Dickson AL, Poss KD. 2015. Epicardial regeneration is guided by cardiac outflow tract and Hedgehog signalling. Nature 522: 226-230. doi:10.1038/na ture 14325

Wei K, Serpooshan V, Hurtado C, Diez-Cuñado M, Zhao M, Maruyama S, Zhu W, Fajardo G, Noseda M, Nakamura K, et al. 2015. Epicardial FSTL1 reconstitution regenerates the adult mammalian heart. Nature 525: 479-485. doi:10 $.1038 /$ nature 15372

Wengerhoff SM, Weiss AR, Dwyer KL, Dettman RW. 2010. A migratory role for EphrinB ligands in avian epicardial mesothelial cells. Dev Dyn 239: 598-609. doi:10.1002/ dvdy.22163

Wessels A, van den Hoff MJ, Adamo RF, Phelps AL, Lockhart MM, Sauls K, Briggs LE, Norris RA, van Wijk B, Perez-Pomares JM, et al. 2012. Epicardially derived fibroblasts preferentially contribute to the parietal leaflets of the atrioventricular valves in the murine heart. Dev Biol 366: 111-124. doi:10.1016/j.ydbio.2012.04.020

Wills AA, Holdway JE, Major RJ, Poss KD. 2008. Regulated addition of new myocardial and epicardial cells fosters homeostatic cardiac growth and maintenance in adult zebrafish. Development 135: 183-192. doi:10.1242/dev .010363

Witty AD, Mihic A, Tam RY, Fisher SA, Mikryukov A, Shoichet MS, Li RK, Kattman SJ, Keller G. 2014. Generation of the epicardial lineage from human pluripotent stem cells. Nat Biotechnol 32: 1026-1035. doi:10.1038/nbt.3002

Wu H, Lee SH, Gao J, Liu X, Iruela-Arispe ML. 1999. Inactivation of erythropoietin leads to defects in cardiac morphogenesis. Development 126: 3597-3605.

Wu M, Smith CL, Hall JA, Lee I, Luby-Phelps K, Tallquist MD. 2010. Epicardial spindle orientation controls cell entry into the myocardium. Dev Cell 19: 114-125. doi:10.1016/j.devcel.2010.06.011

Wu B, Zhang Z, Lui W, Chen X, Wang Y, Chamberlain AA, Moreno-Rodriguez RA, Markwald RR, O'Rourke BP, Sharp DJ, et al. 2012. Endocardial cells form the coronary arteries by angiogenesis through myocardial-endocardial VEGF signaling. Cell 151: 1083-1096. doi:10.1016/j.cell .2012 .10 .023

Yamaguchi Y, Cavallero S, Patterson M, Shen H, Xu J, Kumar SR, Sucov HM. 2015. Adipogenesis and epicardial adipose tissue: a novel fate of the epicardium induced by mesenchymal transformation and PPAR $\gamma$ activation. Proc Natl Acad Sci 112: 2070-2075. doi:10.1073/pnas .1417232112

Yang JT, Rayburn H, Hynes RO. 1995. Cell adhesion events mediated by $\alpha 4$ integrins are essential in placental and cardiac development. Development 121: 549-560.

Zamora M, Manner J, Ruiz-Lozano P. 2007. Epicardiumderived progenitor cells require $\beta$-catenin for coronary artery formation. Proc Natl Acad Sci 104: 18109-18114. doi:10.1073/pnas.0702415104

Zangi L, Oliveira MS, Ye LY, Ma Q, Sultana N, Hadas Y, Chepurko E, Spater D, Zhou B, Chew WL, et al. 2017. Insulin-like growth factor 1 receptor-dependent pathway drives epicardial adipose tissue formation after myocardial injury. Circulation 135: 59-72. doi:10.1161/CIRCU LATIONAHA.116.022064

Zeisberg EM, Tarnavski O, Zeisberg M, Dorfman AL, McMullen JR, Gustafsson E, Chandraker A, Yuan X, Pu WT, Roberts AB, et al. 2007. Endothelial-to-mesenchymal transition contributes to cardiac fibrosis. Nat Med 13: 952-961. doi:10.1038/nm1613

Zhou B, Ma Q, Rajagopal S, Wu SM, Domian I, RiveraFeliciano J, Jiang D, von Gise A, Ikeda S, Chien KR, et al. 2008a. Epicardial progenitors contribute to the cardiomyocyte lineage in the developing heart. Nature 454: 109-113. doi:10.1038/nature07060

Zhou B, von Gise A, Ma Q, Rivera-Feliciano J, Pu WT. 2008b. Nkx2-5- and Isl1-expressing cardiac progenitors contribute to proepicardium. Biochem Biophys Res Commun 375: 450-453. doi:10.1016/j.bbrc.2008.08.044

Zhou B, von Gise A, Ma Q, Hu YW, Pu WT. 2010. Genetic fate mapping demonstrates contribution of epicardiumderived cells to the annulus fibrosis of the mammalian heart. Dev Biol 338: 251-261. doi:10.1016/j.ydbio.2009 .12 .007

Zhou B, Honor LB, He H, Ma Q, Oh JH, Butterfield C, Lin RZ, Melero-Martin JM, Dolmatova E, Duffy HS, et al. 2011. Adult mouse epicardium modulates myocardial injury by secreting paracrine factors. J Clin Invest 121: 1894-1904. doi:10.1172/JCI45529 


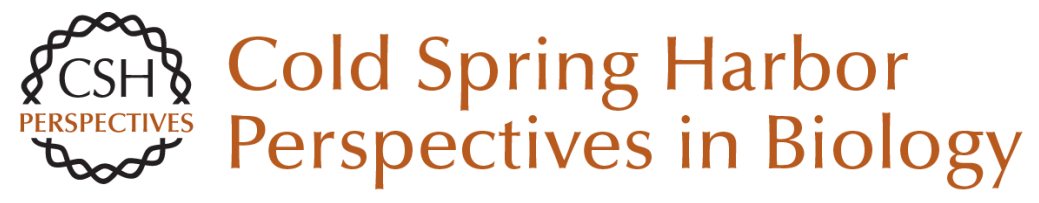

\section{Epicardium in Heart Development}

Yingxi Cao, Sierra Duca and Jingli Cao

Cold Spring Harb Perspect Biol 2020; doi: 10.1101/cshperspect.a037192 originally published online August 26, 2019

\section{Subject Collection Heart Development and Disease}

Epicardium in Heart Development Yingxi Cao, Sierra Duca and Jingli Cao

Cardiac Neural Crest Hiroyuki Yamagishi

The Endocardium and Heart Valves Bailey Dye and Joy Lincoln

Long Noncoding RNAs in Cardiac Development Michael Alexanian and Samir Ounzain

Genetic Basis of Human Congenital Heart Disease Shannon N. Nees and Wendy K. Chung

Cardiopharyngeal Progenitor Specification:

Multiple Roads to the Heart and Head Muscles Benjamin Swedlund and Fabienne Lescroart

Genetic and Epigenetic Control of Heart Development

Brynn N. Akerberg and William T. Pu

Formation and Growth of Cardiac Lymphatics during Embryonic Development, Heart Regeneration, and Disease

Dana Gancz, Gal Perlmoter and Karina Yaniv
In Vivo and In Vitro Genetic Models of Congenital Heart Disease Uddalak Majumdar, Jun Yasuhara and Vidu Garg

Development of the Cardiac Conduction System Samadrita Bhattacharyya and Nikhil V. Munshi

3D Anatomy of the Developing Heart:

Understanding Ventricular Septation

Timothy J. Mohun and Robert H. Anderson

Cardiac Morphogenesis: Specification of the

Four-Chambered Heart

Vincent Christoffels and Bjarke Jensen

The Chicken as a Model Organism to Study Heart

Development

Johannes G. Wittig and Andrea Münsterberg

The First Heartbeat--Origin of Cardiac Contractile

Activity

Richard C.V. Tyser and Shankar Srinivas

Xenopus: Experimental Access to Cardiovascular

Development, Regeneration Discovery, and

Cardiovascular Heart-Defect Modeling Stefan Hoppler and Frank L. Conlon

Reptiles as a Model System to Study Heart

Development

Bjarke Jensen and Vincent M. Christoffels

For additional articles in this collection, see http://cshperspectives.cshlp.org/cgi/collection/



Copyright @ 2020 Cold Spring Harbor Laboratory Press; all rights reserved 